\title{
Orchid in vitro growth as affected by nitrogen levels in the culture medium
}

\author{
Armando R Tavares ${ }^{1}$; Jorge Luiz M Young ${ }^{1}$; Sandra S Ori ${ }^{1}$; Shoey Kanashiro ${ }^{1}$; Giuseppina PP Lima ${ }^{2}$; \\ Edison Paulo Chu'; ${ }^{1}$ Rogério M Suzuki ${ }^{1}$ \\ ${ }^{1}$ IBt, C. Postal 68041, 04045-972 São Paulo-SP; atavares2005@yahoo.com.br; ${ }^{2}$ UNESP, Depto. Biociências, Depto. de Química e \\ Bioquímica; C. Postal 545, 18618-970 Botucatu-SP; gpplima@ibb.unesp.br
}

\begin{abstract}
In vitro cultivation is the main propagation method for the family Orchidaceae, whereas nitrogen is the most important nutrient in the culture media. This work was carried out to study the influence of different nitrogen concentrations on the in vitro growth of the orchid Phalaenopsis amabilis. Nitrogen concentrations varied by altering the ionic balance of the Murashige \& Skoog (MS) culture medium. Plants, 360 days old, were cultivated in liquid MS, modified with 7.5, $15,30,45$, and $60 \mathrm{mM} \mathrm{N}$. After 180 days, we assessed plant and root length, number of leaves and roots, and fresh and dry weight of leaves, roots and plants. Treatments were assigned to completely randomized plots, with four replications. Plots consisted of five three-plant flasks. The lowest nitrogen level $(7.5 \mathrm{mM})$ in the medium induced root development in length, number, and fresh and dry weight. The concentration $30 \mathrm{mM} \mathrm{N}$ stimulated both emission and dry weight accumulation of leaves. The original nitrogen concentration in the MS medium $(60 \mathrm{mM})$ was excessive for the in vitro growth of $P$. amabilis.
\end{abstract}

Keywords: Phalaenopsis amabilis, MS, mineral nutrition, nitrogen.

\section{RESUMO}

Crescimento in vitro de orquídea em função de diferentes concentrações de nitrogênio no meio de cultura

O cultivo in vitro de plantas é o principal método de propagação das plantas da família Orchidaceae, sendo o nitrogênio o nutriente de maior importância dos meios de cultivo. O estudo teve como objetivo avaliar o efeito de diferentes concentrações de $\mathrm{N}$ através de balanço iônico do meio de Murashige \& Skoog (MS-1962) no crescimento in vitro da orquídea Phalaenopsis amabilis. Plantas com 360 dias foram cultivadas em meio MS líquido, modificado com 7,5, 15, 30, 45 e $60 \mathrm{mM}$ N. Após 180 dias avaliou-se o comprimento da planta, número de folhas e raízes, comprimento da raiz e as massas fresca e seca de folhas, raízes e total. Os tratamentos foram dispostos em delineamento inteiramente casualizado, com quatro repetições e parcelas de cinco frascos, com três explantes cada. A menor concentração de $\mathrm{N}(7,5 \mathrm{mM})$ no meio MS induziu o desenvolvimento de raízes em comprimento, número e massas fresca e seca. A concentração de $30 \mathrm{mM}$ de $\mathrm{N}$ estimulou a emissão de folhas e o acúmulo de massa seca de folhas. A concentração original de nitrogênio no meio MS $(60 \mathrm{mM})$ mostrou ser excessiva para o crescimento de P. amabilis cultivada in vitro.

Palavras-chave: Phalaenopsis amabilis, MS, nutrição mineral, nitrogênio.

(Recebido para publicação em 25 de novembro de 2010; aceito em 28 de fevereiro de 2012)

(Received on November 25, 2010; accepted on February, 2012)

$\mathrm{T}_{1}$ he family Orchidaceae is one of the largest and most diversified among the angiosperms, comprising about 700 genera and 25,000 species of terrestrial plants, as well as epiphytes, lithophytes, and saprophytes (Atwood, 1986; Chase et al., 2003). Due to the large number of orchid species and hybrids, there is great diversity of shapes, sizes and colors of leaves and flowers, which opened a wide avenue for the selection of ornamental characteristics of great commercial value. Today, orchids are produced and traded worldwide (Araújo et al., 2005).

The genus Phalaenopsis has high ornamental and commercial relevance. It is one of the few genera within the Orchidaceae whose plants bloom every six months, with long lasting inflorescences. According to Paul \& Starosta (1998), Phalaenopsis has monopodial growth, in which leaves are arranged alternately over the axillary buds. Most of the diversity in Phalaenopsis resulted from the hybridization between $P$. amabilis and P. stuartiana.

The development of the process of plant in vitro micropropagation allowed the efficient exploitation of several ornamental species, as the natural vegetative propagation is often slow and produces few sprouts per plant (Mercier \& Kerbauy, 1997). However, micropropagation in Phalaenopsis presents some difficulties. According to Hinnen et al. (1989), the stagnation of the plant in vitro development observed in Phalaenopsis may be due to nutrient depletion and $\mathrm{pH}$ changes in the medium, competition between plants, and exudation of phytotoxic phenolic compounds that occur within this genus. These factors make it necessary to perform plant subcultivation into fresh culture medium to allow plantlets to sustain a regular in vitro development.

Gribble et al. (2002) showed the importance of mineral nutrition on the in vitro growth of seedlings, emphasizing that there are virtually no studies that address in vitro plant mineral uptake, neither that focus on culture medium optimization for mineral absorption. Once in vitro plantlets grow in non-ideal conditions and there are no roots, mineral uptake mechanisms are different from 
those of plants growing under in vivo conditions. Mineral supply in the culture medium is an essential part of plant micropropagation. It is also important to know the optimal conditions, which vary widely with genotypes and cultivation systems. There is evidence that when concentration gradients between the medium and the explant tissue differ, uptake takes place through diffusion (Williams, 1993). According to Niedz \& Evans (2007), to understand the effects of mineral nutrients on plant in vitro responses, it is necessary to study the ions, not the salts.

The major difficulties in orchid micropropagation are related to the time required for (1) the production of seedlings from selected hybrids and (2) identifying the suitable culture medium for each species. Thus, this study aimed to test the effects of different nitrogen concentrations in the Murashige and Skoog (MS-1962) liquid medium over plantlet in vitro development in the orchid Phalaenopsis amabilis.

\section{MATERIAL AND METHODS}

Plants of Phalaenopsis amabilis with 360 days (in average with 1.75 cm leaf length, 2.05 in root length, 2.9 leaves, 3.6 roots, $0.085 \mathrm{~g}$ leaf fresh mass, $0.107 \mathrm{~g}$ root fresh mass, 0.191 $\mathrm{g}$ total fresh mass, $0.004 \mathrm{~g}$ leaf dry mass, $0.012 \mathrm{~g}$ root dry mass and 0.016 $\mathrm{g}$ total dry mass), which grew out of in vitro germinated seeds, were placed over acrylic foam in $360 \mathrm{~mL}$ flasks, containing $60 \mathrm{~mL}$ of the Murashige and Skoog (MS-1962) liquid medium. MS was modified to $7.5,15,30,45$ and 60 $\mathrm{mM}$ (the MS original concentration) of nitrogen, with $\mathrm{pH}$ adjusted to 5.8 (Table 1). Plants were subcultivated in liquid medium every 60 days, totaling six months of culture $\left(22 \mu \mathrm{mol} \mathrm{m} \mathrm{m}^{-2} \mathrm{~s}^{-1}\right.$ of photosynthetic active radiation, 12-h photoperiod and $26 \pm 2^{\circ} \mathrm{C}$ ). We assessed shoot length, from the stem base to the tip of the longest leaf, number of leaves, number and length of roots longer than $1 \mathrm{~mm}$, and fresh and dry mass of leaves, roots and plants.

The experiment consisted of five treatments (nitrogen concentrations), with four replications and plots of five 3-plant flasks (60 plants per treatment), arranged in a completely randomized design (Nogueira, 1994) for all characteristics. Data were submitted to regression analysis. The $\mathrm{F}$ test was performed using the software SANEST (Zonta, 1991).

\section{RESULTS AND DISCUSSION}

The nitrogen concentration in the culture medium did not affect significantly leaf length (Figure 1A). However, the number of leaves was significantly altered by the changes in $\mathrm{N}$ concentration, reaching the highest value at $35.15 \mathrm{mM}$ of $\mathrm{N}$ (Figure 1B); as it were also number and length of roots: as $\mathrm{N}$ in the medium increased, both characteristics presented a linear decrease (Figures 1C and 1D). Similar results were obtained by Kanashiro et al. (2007) with the bromeliad Aechmea blanchetiana grown in the MS medium; authors observed a stimulus to a linear increase in the number of leaves and decrease in the number of roots with mounting $\mathrm{N}$ concentrations in the medium. Grossi (2000) also found a similar behavior in the bromeliad $A$. nudicaulis, i.e., more leaves at the highest $\mathrm{N}$ concentrations (between 1.78 and $30 \mathrm{mM}$ ) and higher amount of roots in the lowest $\mathrm{N}$ concentration (1.78 $\mathrm{mM}$ ), with a reduction in the root system size. Russowski \& Nicoloso (2003), working with the Brazilian ginseng, reported a higher number of roots in $50 \%$ concentration of ammonium nitrate in MS medium, with the number of roots tending to fall at higher $\mathrm{N}$ concentrations. Sweby et al. (1994), when growing shoots of Nicotiana tabacum in modified MS medium, did not observe significant changes in root length with the increase in $\mathrm{N}$ concentration in the medium up to 60 $\mathrm{mM}$; however root growth was inhibited at $120 \mathrm{mM} \mathrm{N}$. On the other hand, Gomes \& Shepherd (2000) showed that, nor the length of the longest root, neither the number of roots were significantly altered by the increase in $\mathrm{N}$ concentration in the MS medium in Sinningia allagophylla. Kerbauy (1993) found in Oncidium varicosum that high $\mathrm{N}$ concentrations, especially as ammonium, inhibit root growth, as we also observed in the current work. Hinnen et al. (1989) showed that in Phalaenopsis hybrid seedlings, high concentrations of nitrate and ammonium were deleterious to root growth.

We did not observe significant differences in leaf fresh weight due to the increase in $\mathrm{N}$ concentration in the medium (Figure 2A). However, root (Figure 2B) and total (Figure 2C) fresh weight, as well as root (Figure 2E) and total (Figure 2F) dry weight had a significant linear regression with $\mathrm{N}$ concentrations: for each $\mathrm{mM}$ of $\mathrm{N}$ added to the medium, there was a decrease of 0.003 and $0.0029 \mathrm{~g}$ in root and total fresh weight respectively, and 0.0003 and $0.0002 \mathrm{~g}$ in root and total dry weight respectively (Figure 3). Considering leaf dry weight, only the quadratic regression was significant, with the characteristic reaching its maximum at $37.5 \mathrm{mM} \mathrm{N}$ (Figure 2D). Dijk \& Eck (1995 a,b), when studying three species of the orchid Dactylorhiza observed that each species had a different response to the increase in $\mathrm{N}$ concentration (from 0 to $12 \mathrm{mM}$ ) in the medium: while fresh

Table 1. Ion concentration and respective sources in a modified Murashige \& Skoog (MS1962) medium for Phalaenopsis amabilis in vitro cultivation (concentrações dos íons e suas respectivas fontes utilizados no meio de cultura Murashige \& Skoog (1962) modificado para crescimento de Phalaenopsis amabilis in vitro). São Paulo, IBt, 2007.

\begin{tabular}{lcccrrr}
\hline \multirow{2}{*}{ Ions } & \multirow{2}{*}{ Sources } & \multicolumn{5}{c}{ N concentration $(\mathbf{m M})$} \\
\cline { 3 - 7 } & & $\mathbf{7 . 5}$ & $\mathbf{1 5}$ & $\mathbf{3 0}$ & \multicolumn{1}{c}{$\mathbf{4 5}$} & \multicolumn{1}{c}{$\mathbf{6 0}^{*}$} \\
\hline $\mathrm{NO}_{3}{ }^{-}$ & $\mathrm{KNO}_{3}$ & 3.746 & 3.746 & 3.746 & 3.746 & 3.746 \\
$\mathrm{NO}_{3}^{-}$ & $\mathrm{NH}_{4} \mathrm{NO}_{3}$ & 1.877 & 5.627 & 13.127 & 20.627 & 28.140 \\
$\mathrm{NH}_{4}^{+}$ & $\mathrm{NH}_{4} \mathrm{NO}_{3}$ & 1.877 & 5.627 & 13.127 & 20.627 & 28.140 \\
\hline
\end{tabular}

*Original N concentration in the Murashige \& Skoog medium, 1962 (concentração original de N no meio de Murashige \& Skoog, 1962). 


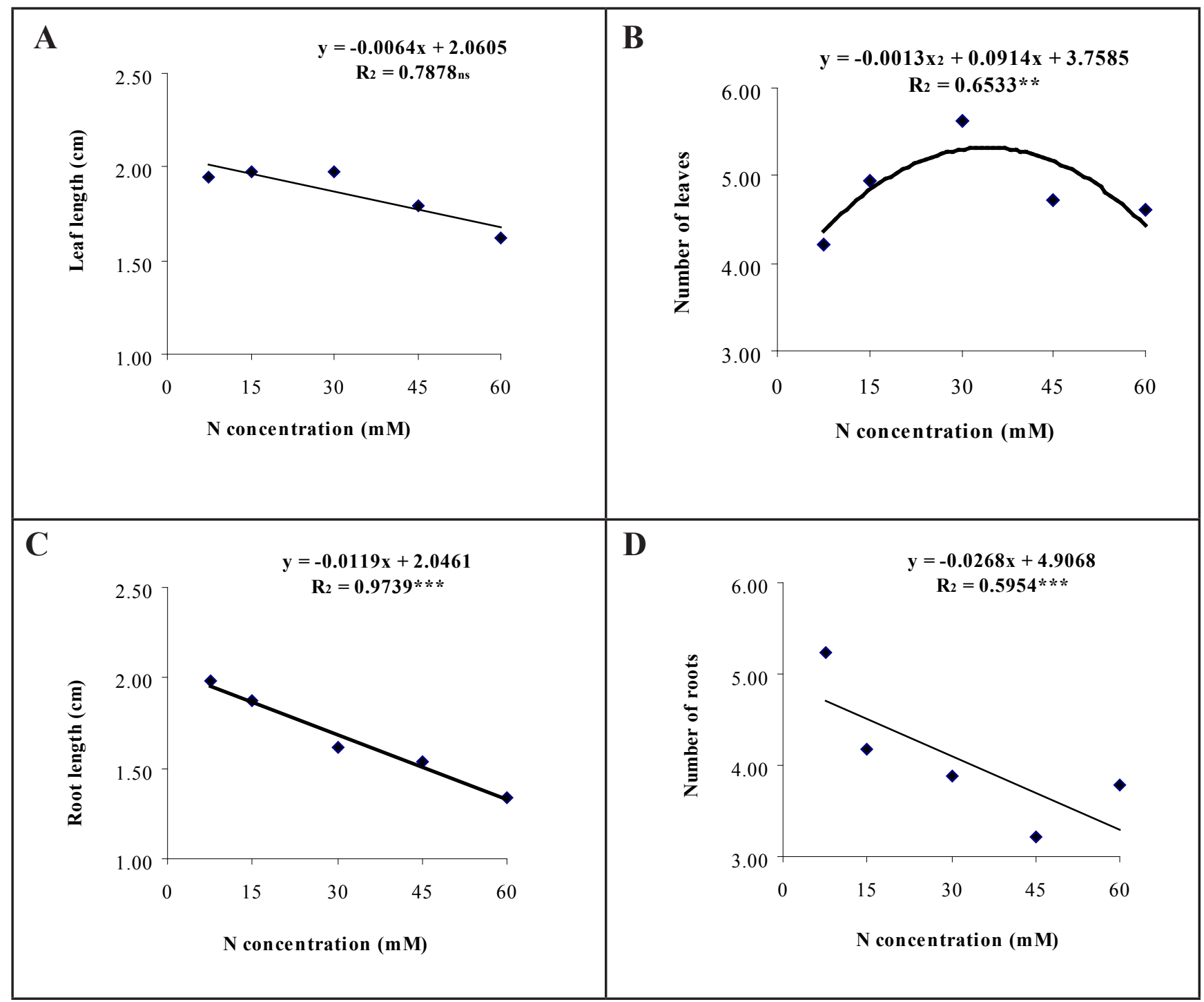

Figure 1. Adjusted regression curves for length (A) and number of leaves (B) and length (C) and number of roots (D) of Phalaenopsis amabilis seedlings grown in vitro for 180 days in different nitrogen concentrations in MS medium (funções de regressão ajustadas para comprimento (A) e número de folhas (B) e comprimento (C) e número de raízes (D) de plantas de Phalaenopsis amabilis cultivadas in vitro por 180 dias em diferentes concentrações de nitrogênio em meio MS). São Paulo, IBt, 2007.

weight fell in D. incarnate, it increased in D. praetermissa and remained stable in D. majalis. Evans (1993) studied nine cultivars of Solanum spp. grown on MS medium with different $\mathrm{N}$ concentrations (from 20 to $60 \mathrm{mM}$ ) and concluded that the increase in $\mathrm{N}$ concentration did not induce significant effects on shoot fresh weight. Kanashiro et al. (2007) obtained similar results in A. blanchetiana for root and plant dry weight and leaf and total fresh weight, all characteristics decreasing linearly with increasing $\mathrm{N}$ concentrations in the MS medium. Ribeiro et al. (2002) studied the relationship between potassium nitrate and ammonium nitrate on the in vitro growth of coffee shoots and came to the conclusion that concentrations of 75 and $100 \%$ of potassium nitrate in the MS medium significantly promoted the accumulation of leaf and stem fresh weight until the concentration of ammonium nitrate of 54 and $47 \%$ respectively. Russowski \& Nicoloso (2003), working with the Brazilian ginseng, reported the highest total and root dry weight at the concentrations of $60 \%$ and $80 \%$ of ammonium nitrate in the MS medium, with a tendency to fall at higher $\mathrm{N}$ concentrations.

Avila et al. (1998) studied the effect of the medium physical phase (liquid or solid) and different concentrations of the ions $\mathrm{NH}_{4}^{+}$and $\mathrm{NO}_{3}^{-}$on the in vitro growth of potato plants and reported that the use of liquid medium enhanced the deleterious effects (decrease in dry weight) of the ratio $\mathrm{NH}_{4}^{+}: \mathrm{O}_{3}^{-}$, suggesting that $\mathrm{N}$ concentration in the MS medium can be excessive if the liquid form is preferred. The optimal salt concentrations in liquid media are different from those of solid media due to restrictions to the diffusion speed and nutrient gradient (solid medium) and to the oxygen needed for explant respiration (liquid medium) (Caldas et al., 1998).

According to Hinnen et al. (1989), $\mathrm{N}$ seems to be the most important 


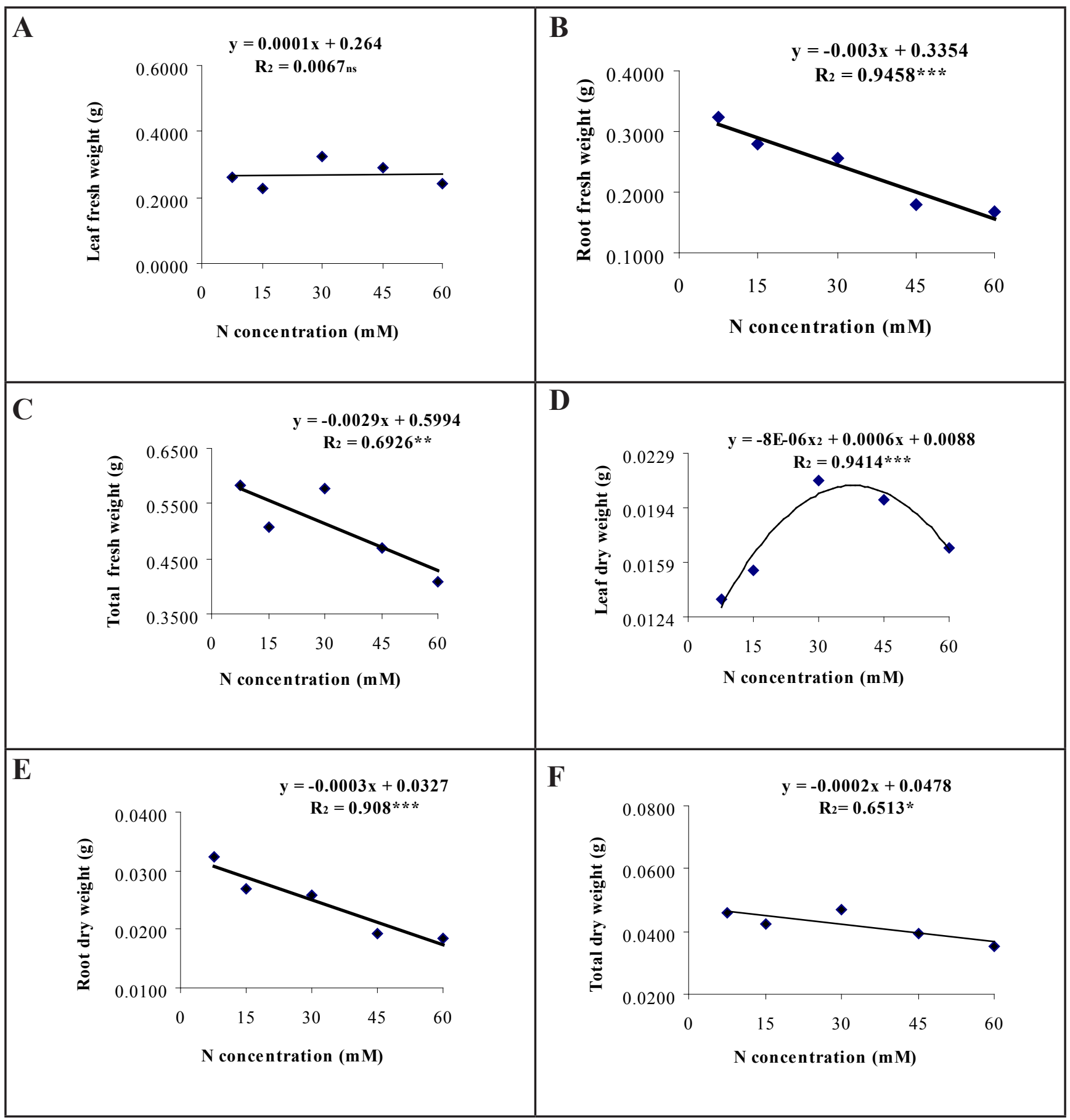

Figure 2. Adjusted regression curves for fresh weight of leaves (A), roots (B) and total (C) and dry weight of leaves (D), roots (E) and total (F) of Phalaenopsis amabilis seedlings grown in vitro for 180 days, in different nitrogen concentrations in MS medium (funções ajustadas de regressão para massa fresca de folhas (A), raízes (B) e total (C), massa seca de folhas (D), raízes (E) e total (F) de plantas de Phalaenopsis amabilis cultivadas in vitro por 180 dias, em em diferentes concentrações de nitrogênio em meio MS. São Paulo, IBt. 2007.

element in the in vitro nutrition of Phalaenopsis when the Gamborg B5 medium is used (Gamborg et al., 1976), since the addition of $\mathrm{NH}_{4}^{+}$and $\mathrm{NO}_{3}^{-}$ promoted shoot growth and hampered root development. According to these authors, it is possible to stimulate separately root and shoot growth. Thus, for root growth the medium should contain $387 \mathrm{mg} \mathrm{L}^{-1}(\mathrm{NH} 4)_{2} \mathrm{SO}_{4}$ and 445 $\mathrm{mg} \mathrm{L} \mathrm{NaNO}_{3}$, while for shoot growth, $1373 \mathrm{mg} \mathrm{L}^{-1}(\mathrm{NH} 4)_{2} \mathrm{SO}_{4}$ and $1593 \mathrm{mg}$ $\mathrm{L}^{-1} \mathrm{NaNO}_{3}$.

Our current results allow us to conclude that for the in vitro propagation of Phalaenopsis amabilis $\mathrm{N}$ concentration in the MS medium should be reduced to $30 \mathrm{mM} \mathrm{N}$ during the sprouting and growth stages, and to $7.5 \mathrm{mM}$ for rooting. The original concentration of the MS medium (60 


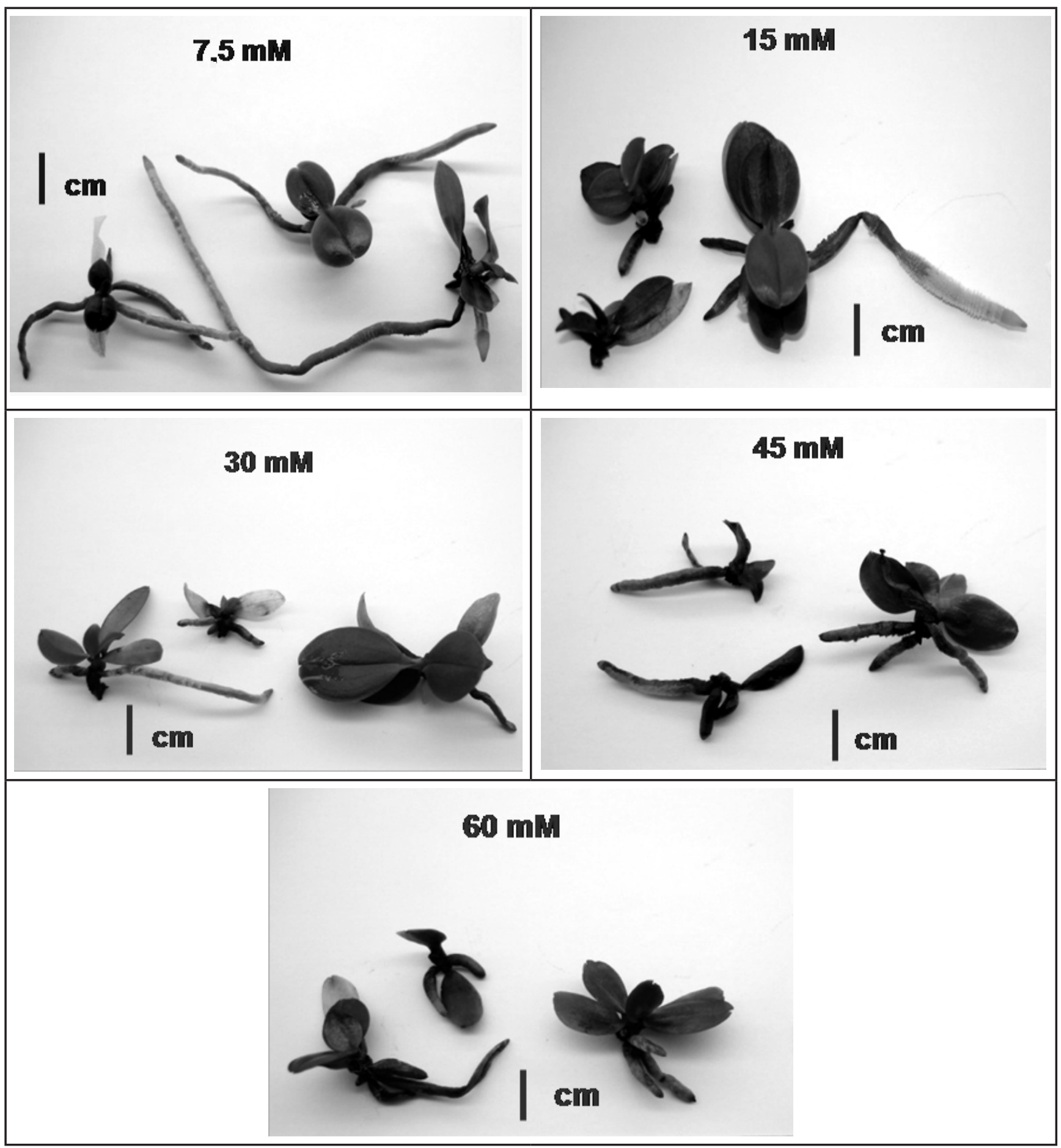

Figure 3. 180-day old Phalaenospsis amabilis plantlets grown in vitro in modified MS medium with 7.5, 15, 30, 45 and $60 \mathrm{mM}$ of nitrogen (plantas de Phalaenospsis amabilis após 180 dias de cultivo in vitro, em meio MS modificado com as concentrações de 7,5, 15, 30, 45 e 60 mM de nitrogênio). São Paulo, IBt. 2007.

$\mathrm{mM} \mathrm{N}$ ) proved to be exaggerated for the in vitro cultivation of this species.

\section{ACKNOWLEDGEMENTS}

Authors would like to thank Ori Orchid Nursery for the plants used in this study and the National Council for Scientific and Technological
Development $(\mathrm{CNPq})$ for the grant awarded to AR Tavares (Process №. 305776/2009-6).

\section{REFERENCES}

ATWOOD JT. 1986. The size of the Orchidaceae and the systematic distribution of epiphytic orchids. Selbyana 9: 171-186.
AVILA AL; PEREYRA SM; ARGÜELLO JA. 1998. Nitrogen concentration and proportion of $\mathrm{NH}_{4}-\mathrm{N}$ affect potato cultivar response in solid and liquid media. HortScience 33: 336-338

CALDAS LS; HARIDASAN P; FERREIRA ME. 1998. Meios nutritivos. In: TORRES AC; CALDAS LS; BUSO JA (eds). Cultura de Tecidos e Transformação Genética de Plantas. Brasília: Embrapa Imformação Tecnológica/ 
Embrapa Hortaliças. p. 87-132.

CHASE MW; CAMERON KM; BARRET RL; FREUDENSTEI JV. 2003. DNA data and Orchidaceae systematics: a new phylogenetic classification. In: DIXON KW; KELL SP; BARRETT RL; CRIBB PJ (eds). Orchid Conservation. Kota Kinabalu: Natural History Publications. p. 69-89.

DIJK E; ECK N. 1995a. Axenic in vitro nitrogen and phosphorus responses of some Dutch marsh orchids. New Phytologist 131: 353-359.

DIJK E; ECK N. 1995b. Ammonium toxicity and nitrate response of axenically grown Dactylorhiza incarnata seedlings. New Phytologist 131: 361-367.

EVANS NE. 1993. A preliminary study on the effects of nitrogen supply on the growth in vitro of nine potato genotypes (Solanum spp.). Journal of Experimental Botany 44: 837-841.

GAMBORG OL; MURASHIGE T; THORPE TA; VASIL IK. 1976. Plant tissue culture media. In Vitro 12: 473478.

GOMES MAN; SHEPHERD SLK. 2000. Estudo de nutrição mineral in vitro relacionado à adaptação de Sinningia allagophylla (Martius) Wiehler (Gesneriaceae) às condições de cerrado. Revista Brasileira de Botânica 23: 153-159.

GRIBBLE K; CONROY JP; HOLFORD P; MILHAM PJ. 2002. In vitro uptake of minerals by Gypsophila paniculata and hybrid eucalypts, and relevance to media mineral formulation. Australian Journal of Botany 50: 713-723.

GROSSI F. 2000. Aspectos da nutrição nitrogenada in vitro e atividade da redutase de nitrato em uma espécie de bromélia. Piracicaba: Universidade de São Paulo, 116p (Tese doutorado).

HINNEN MGJ; PIERIK RLM; BRONSEMA FBF. 1989. The influence of macronutrients and some other factors on growth of Phalaenopsis hybrid seedlings in vitro. Scientia Horticulturae 41: 105-116.

KANASHIRO S; RIBEIRO RCS; GONÇALVES AN; DIAS CTS; JOCYS T. 2007. Efeito de diferentes concentrações de nitrogênio no crescimento de Aechmea blanchetiana (Baker) L.B. Sm. cultivada in vitro. Hoehnea 34: 59-66.

KERBAUY GB. 1993. Indução in vitro de protocormóides em raízes de Oncidium varicosum. Efeito de fontes nitrogenadas, auxinas e citocininas. Revista Brasileira de Botânica 16: 1-8.

MERCIER H; KERBAUY GB. 1997. Micropropagation of ornamental bromeliads (Bromeliaceae). In: BAJAJ YPS (ed). Biotechnology in Agriculture and Forestry: high tech and micropropagation VI. Berlin: Springer-Verlag, p. 43-57.

MURASHIGE T; SKOOG F. 1962. A revised medium for rapid growth and bioassays with tobacco tissue cultures. Physiologia Plantarum
15: 473-497.

NIEDZ RP; EVANS TJ. 2007. Regulating plant tissue growth by mineral nutrition. In Vitro Cellular Developmental Biology-Plant 43: 370-381.

NOGUEIRA MCS. 1994. Estatística experimental aplicada à experimentação agrícola. Piracicaba: ESALQ. 204p.

PAUL M; STAROSTA P. 1998. Orchids. London: Evergreen Press. 126p.

RIBEIRO LS; PASQUAL M; MACIEL ALR; ARANTES ES; CHAGAS EA. 2002. Fontes de nitrogênio na micropropagação de Coffea arabica. Scientia Agraria 3: 107-112.

RUSSOWSKI D; NICOLOSO FT. 2003. Nitrogênio e fósforo no crescimento de plantas de ginseng brasileiro [Pfaffia glomerata (Spreng.) Pedersen] cultivadas in vitro. Ciência Rural 33: 57-63.

SWEBY DL; HUCKETT BI; WATT MP. 1994. Effects of nitrogen nutrition on salt-stressed Nicotiana tabacum var. Samsun in vitro plantlets. Journal of Experimental Botany 45: 995-1008.

WILLIAMS RR. 1993. Factors determining mineral uptake in vitro. Acta Horticulturae 289: 165-169.

ZONTA EP; MACHADO AA. 1991. Manual do Sanest: sistema de análise estatística para microcomputadores. Pelotas: Universidade Federal de Pelotas. 102p. 